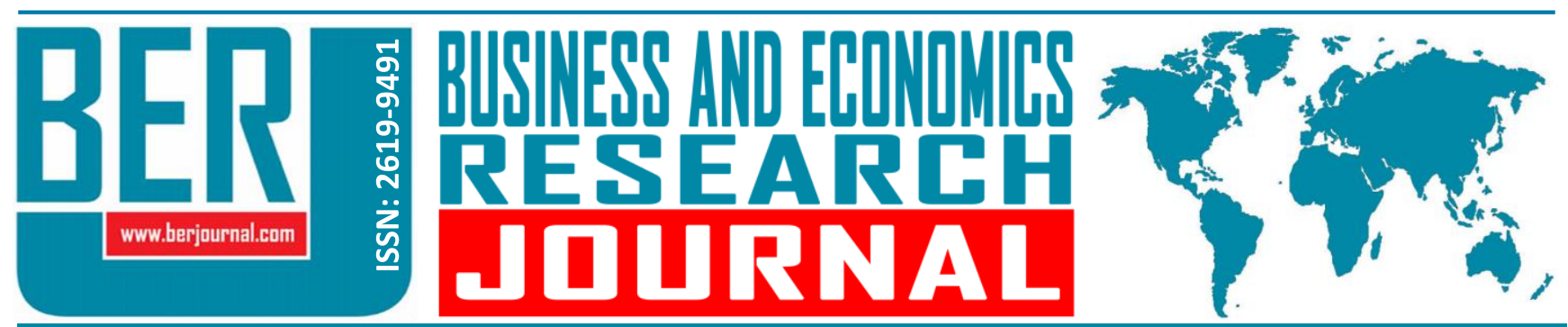

Business and Economics Research Journal Vol. 11, No. 1, 2020, pp. 213-227 doi: 10.20409/berj.2020.246

\title{
Mediating Role of Perceived Internal Status on the Relationship Between Perceived Psychological Empowerment and Loneliness at Workplace
}

\author{
Engin Kanbur ${ }^{a}$, Aysun Kanbur ${ }^{b}$
}

\begin{abstract}
The aim of this research is to examine whether or not perceived internal status has a mediating role on the relationship between perceived psychological empowerment and loneliness at workplace and its subdimensions. The sample of the research is constituted by 219 employees who are affiliated to the public institutions in the body of governorship of one of our province. For gathering the data, questionnaire technique was used. Correlation analysis and regression analysis were utilized for determining the relationships between variables of the research and testing the hypotheses. According to the findings, it can be seen that perceived psychological empowerment has positive relationship with perceived internal status and negative relationship with loneliness at workplace. It is determined in this research that perceived internal status has a full mediating role on the relationship between perceived psychological empowerment and loneliness at workplace. This mediating role shapes as partial mediating role on lack of social companionship side while there isn't observed any mediating role on emotional deprivation side as subdimensions of loneliness at workplace.
\end{abstract}

\begin{abstract}
Keywords: Perceived Psychological Empowerment, Loneliness at Workplace, Emotional Deprivation, Lack of Social Companionship, Perceived Internal Status
\end{abstract}

JEL: M10, M19
Received : 11 September 2019

Revised : 01 November 2019

Accepted : 09 December 2019

Type : Research

\section{Introduction}

In today's ruthless competitive environment, for competing with their rivals and providing sustainable competitiveness, organizations need employees who have characteristics such as being qualified, devoted, proactive, knowledgeable, experienced, creative, entrepreneurial and as well as empowered. Employees, on the other hand, are involved in organizations to feel belonging to a group, to socialize, to have a career, to meet their needs, to secure their future and to reduce uncertainty for themselves. Employees will increase their sense of belonging with their organizations and will not feel lonely as long as their organizations support and empower them, and they appreciate this empowerment positively.

Human is a social living existence and must be with other people in order to be able to maintain his life on a regular basis. One of the most popular complained topics of the human of this era is the social and emotional loneliness that especially comes into the mind in modern societies. At this point, in the context of this study, loneliness refers to the mental state and mood of individuals due to their distant mutual social interaction, rather than being physically distant from each other (Mercan et al., 2012: 215). Providing peace

a Assoc. Prof., PhD., Kastamonu University, School of Civil Aviation, Aviation Management, Kastamonu, Turkiye, ekanbur@kastamonu.edu.tr (ORCID ID: 0000-0002-6261-9314)

b Assoc. Prof., PhD., Kastamonu University, Economics and Administrative Sciences Faculty, Department of Business Administration, Kastamonu, Turkiye, akanbur@kastamonu.edu.tr (ORCID ID: 0000-0002-5950-0865) 
of mind at work and creating a safe working environment is important for the individual. It is very important to prevent loneliness, which is a feeling emanating from the negativities caused by the deficiencies of such situations, and it causes many negative effects on the employees if it is not prevented (Lam \& Lau, 2012; Keser \& Karaduman, 2014: 180).

In this context, the effect of employees' perceptions of psychological empowerment on their loneliness in the workplace and whether the perceived internal status in this effect has a mediating role is the problematic of this study. In this study, a detailed review of the literature on the variables was examined. It is a necessity for humanbeing to understand the factors behind loneliness for coping with it. On the other hand, it is believed that organizations may give their employees the strenght through empowerment for coping with the problems which surrounded them. Loneliness can also be thought as a problem in the workplace due to its negative results both for the employees and organizations. When it is experienced, the ways to get rid of this situation is searched. Empowerment is the power in any circumstance to overcome the difficulties. Thus, what it is aimed to explain in this study is whether empowerment addresses to get over difficulties of loneliness. Besides, no study examining the mediating role of perceived internal status in the effect of perceived psychological empowerment on loneliness in the workplace was found. In this context, researching a topic that has not been researched in the literature and sharing its results is extremely important both in terms of its importance and contribution to the literature and the need for such research. Moreover, it is important to emphasize the relationship between empowerment and loneliness to become aware of alleviating the effects of loneliness at workplace. In addition, the results of the study are believed to be important because it demonstrates the effect of perceived psychological empowerment on loneliness for the public sector employees and (or) those who wish to work for public sector.

In this study, it is aimed to examine the mediating role of perceived internal status on the relationship between perceived psychological empowerment and loneliness at workplace. Organizations need knowledgeable, experienced, proactive, creative and innovative employees to reach their goals, compete with their rivals and ensure sustainability. Such kind of features do not occur spontaneously in employees and its necessery for organizations to understand the shortcomings of employees and empowering them, and to increase their sense of loyalty. In accordance with the theory of social identity, employees want to be a loyal member of their organization and desire to feel good and sufficient. Employees who perceive their empowerment will feel that they are qualified, knowledgeable, valuable and not alone in the organization. This will increase their intraorganizational communication skills, their commitment and hence their performance. On the contrary, employees who perceive that they are not empowered become alienated towards their organization and feel loneliness at workplace. Therefore, the relationship between psychological empowerment perception of employees and their feelings of loneliness at workplace required to be well understood. In this context, firstly, the related concepts were explained in the context of literature for this aim. Then, the methodology of the research was structured and statistical analyses were conducted for testing the hypotheses. As a conclusion, findings were presented and evaluated.

\section{Theoretical Framework}

\subsection{Perceived Psychological Empowerment}

Empowerment can be defined as upper management's sharing of knowledge, information and power with lower level employees, and giving authority and responsibility to them, and also, employees' taking care of the work they have done and taking responsibility (Hales \& Klidas, 1998: 89; Kesen, 2015: 6532). According to Conger and Kanungo (1988), who first expressed the concept of empowerment, empowerment is an intrinsic motivational tool and perceptions of employees to the work and required work roles they have done (Toplu \& Akça, 2013: 225). Empowerment will make the employee feel stronger in order to meet the requirements of competition. The concept of empowerment which initially conceptualized through managerial practices such as participation in decisions, provision of access to resources and delegation of authority is now examined with the aspect of psychological empowerment (Kanbur, 2018: 148). 
In organizational view, psychological empowerment is frequently used in the literature as motivating, increasing employees' ability to do their work, reviving their values and feelings of autonomy, activating them and making them feel psychologically safe (Çalışkan, 2011: 79). Psychological empowerment includes efforts and beliefs of employees to achieve the goals of their role within the organization and their awareness on the factors that prevent or increase the achievement of these goals (Zimmerman, 1995: 582). Psychological empowerment is a psychological process that focuses on how employees will do their jobs better, instead of focusing on managerial practices such as sharing existing power with employees. This process involves the personal beliefs that employees have about their roles in the organization (Spreizer, 2007: 57; Altındiş \& Özutku, 2011: 166). Employees may have a higher internal motivation with higher levels of psychological empowerment. This is expected to result in intensive attention to given tasks, more effort, resistance to difficulties and improved task strategies (Hall, 2008: 146). Definitions of psychological empowerment have two common points. These are the resharing of the power within the organization and the involvement of employees in organizational processes (Yıldırım, 2011: 98).

Spreitzer (1995) examines psychological empowerment in four dimensions as meaning, competence, self-determination, and impact, and argues that it reflects a more active orientation towards the role of employee in his work (Spreitzer, Kizilos \& Nason, 1997: 681; Hu \& Leung, 2003: 368; Laschinger et al., 2004: 529; Taştan, 2012: 229; Singh \& Jha, 2014: 21; Gupta \& Handa, 2015: 56; Kanbur, 2018: 2). Meaning can be defined as the harmony between the values, beliefs, attitudes, experiences that exist in employee and his behaviors, and the work he has done, and necessities and purposes of the work (Spreitzer, 1995: 1443; Yürür \& Demir, 2011: 314). Competence is related to the level of confidence that employees have towards themselves and their ability to organize work and actions better (Bandura, 1995: 26; Sürgevil, Tolay \& Topoyan, 2013: 5374; Kanbur, Canbek \& Özyer, 2016: 20). Self-determination refers to the freedom of employees to make decisions by themselves about how to do things independently from the upper level management, what kind of efforts will be spent, and which methods will be used (Spreitzer et al., 1996; Karakaş \& Serçek, 2014: 92). Impact is the belief of an employee that he can have an effect on strategic, managerial, or functional activities and outcomes at his workplace (Avolio et al., 2004: 953; Whitakera \& Westerman, 2014: 270).

\subsection{Loneliness at Workplace}

Loneliness is an undesired mood that an individual feels himself moving away or being moved away from other people and feels deprived of close and confident relationships within his social environment (Akar, 2015: 407). Loneliness refers to a permanent emotional disorder that arises as a result of an individual's feelings of being misunderstood and rejected, lack of social sharing, and alienation (Rook, 1984: 1390). Loneliness, by the closure of his consciousness and emotions on to himself, is the inability of human to get out of the cocoon that he made due to breaking out of ties of belonging to the external world (Wright, 2012: 48; Armağan, 2014: 28; Rokach, 2014: 50). Being as a distressing emotion that has emerged as a result of quantitative and qualitative deficiencies in the social relationship network of an individual, it is defined as an indication which demonstrates that the individual has some deficiencies in his social relationships (Oğuz \& Kalkan, 2014: 788). In a broader sense, the concept of loneliness can be expressed as an individual's inability to adapt to his environment, feeling of being orphaned and not to be understood, and a condition in which harmony is deteriorated and unhappiness manifests itself. This condition brings with it many negative situations such as decrease in social relations and increase in feeling of stress (Cindiloglu et al., 2017: 192).

Loneliness at work often expresses social isolation, leaving alone due to social environment, inadequacies in socialization and the situation of being on its own (Wright, Burt \& Strongman, 2006; Erdil \& Ertosun, 2011: 507; Ghadi, 2017: 83; Peng et al., 2017: 510). Loneliness at workplace is accepted as a different concept from loneliness in everyday life, thus, it is separated from general loneliness because it is only seen as effective in business environment (Doğan, Çetin \& Sungur, 2009: 272; Çetin \& Alacalar, 2016. 194). Therefore, unlike general loneliness, loneliness at workplace can be only effective in the business environment. In other words, an individual who has very satisfying and healthy relationships in his daily life and who doesn't live feelings of loneliness might have difficulties in establishing social relationships and 
getting social support in the work environment (Demirbaş \& Haşit, 2016: 139). It can be seen that loneliness at workplace effects psychological well-being and work performance negatively. The lack of social support and have to do the work alone can be more effective on the loneliness at workplace (Karakaya, Büyükyılmaz \& Ay, 2015: 82). It is also expected that the most obvious consequences of loneliness at workplace are reduced productivity and reduced job satisfaction of employees. Employees who can not exhibit their performance at work due to loneliness feel unsuccessful and see themselves as inadequate and this situation cause their job satisfaction to decrease (Eroğluer \& Yılmaz, 2015: 287).

In the workplace, loneliness is examined by two sub-dimensions as emotional deprivation and lack of social companionship (Weiss, 1973; Russell et al., 1984; Wright et al., 2006; Kunst, Bogaerts \& Winkel, 2010: 420). Emotional deprivation is defined as an employee's ability to close himself against other employees, avoiding sharing feelings and thoughts with other employees, and thoughts about not understood by colleagues (Wright, 2005). Emotional deprivation is usually caused by not establishing close relationship with an other individual and includes feelings of anxiety and emptiness (Aykan, 2014: 415). Lack of social companionship is the employee's inability to participate in the social network at work and not seeing himself as a part of the social network at work (Weiss, 1973). Lack of social companionship involves an individual's social relationships and is often associated with depression and distress due to lack of social networking (Başoğlu et al., 2016: 68). The working individual who lives loneliness in the aspect of lack of social companionship does not see himself as a part of the group of friends in the working environment by not getting involved to social platforms and social activities in the workplace (Mercan et al., 2012 ).

\subsection{Perceived Internal Status}

In the framework of the social exchange theory, it can be expressed that the internal status perceived by the individual is based on the exchange relation between the organization and the individual. The successfulness or unsuccessfulness of this exchange relation of the individual lived with the organization results in the individual's feeling of belonging or not belonging to the organization (Akdoğan \& Köksal, 2014: 28). The concept of belonging includes the experience of the individual of being in harmony with a system, and as well as the individual's sense of being valued and accepted within this system. Therefore, belonging is the influence and sensitivity of individual towards society with his social participation and the level of integration to society (Ayazlar \& Ayazlar, 2016: 1544). When the combination of organizational socialization practices and benefits offered to individual by organization points out to individual that he has achieved to access to the status of intra-group members of the organization, the internal status perception is formed on the individual (Knapp et al., 2014: 274).

The perceived internal status is regarded as a positive and effective connection formed between the individual and the organization, and a feature that is effective in maintaining this connection (Hidalgo \& Hernandez, 2001: 274). The perceived internal status focuses on employees' belonging to organization (Wang \& Kim, 2013: 390; Horng et al., 2016: 57). This concept is a perception regarding that the individual feels himself as a part of the organization and he has an important role in the realization of the activities (Çakal \& Özdemir, 2016: 106). The perceived internal status expresses the individual's sense of gaining an "individual position" and "acceptance" in the organization (Masterson \& Stamper, 2003: 483). Perceived internal status is the belief of an individual who works within a certain organization regarding that what a degree he is a part or intragroup member of the organization (Stamper \& Masterson, 2002: 876; Hui, Lee \& Wang, 2014: 440;). The perception of internal status relatively expresses the perception that the individual contributes positively to the workplace, and the internal status perceived by individuals who believe that they contribute to the workplace is also higher (Kim, Hon \& Crant, 2009: 96).

The perceived internal status also includes emotional commitment of individual to organization. Individuals with high perceived internal status define themselves as a member of the organization, they are participating in the goals and values of the organization, behaving in the way organization expected from them, and have high intentions to continue working in the organization (Ouyang, Lam \& Wang, 2015). It is also stated that they will carry out certain activities such as accepting extra responsibilities related to the organization, performing various tasks in order to help other members of the organization, and making 
suggestions for the development of work processes (Stamper, Masterson \& Knapp, 2007: 314). Individuals with a strong sense of internal status feel that they are a central and important part of the organization, and this feeling meets the needs of belonging of the individuals (Knapp et al., 2014: 274).

The way of creating differences of an ingroup and an outgroup in the organization by using social exchange relationship could be to offer specific awards and motives to both of the groups. Motivating factors will direct individuals to make more effort for the organization, and as the cycle between motives and contributions continues, some individuals will be relatively accepted more valuable for the organization as compared to others, and internal and external group employees will emerge within the organization (Stamper \& Masterson, 2002: 876). Different patterns of behaviors for employees in an organization provide signs that employees have perceived or not perceived the internal status, and these behaviors also influence employees' perceptions about their organizational membership (Buonocore, Metallo \& Salvatore, 2009).

\subsection{Relationship Between the Variables of the Research}

According to Abraham Maslow's Hierarchy of Needs theory and Clayton Alderfer's ERG theory, people are expected to meet the expectations, to overcome difficulties and to increase efficiency and performance as their physiological, psychological and sociological needs are met, their knowledge, experience and communication skills are improved. Otherwise, the trust and commitment of the employees whose needs are not met will decrease and they will feel lonely (Evans \& Lindsay, 1993: 32; Robinson \& Decenzo, 2001: 314; Arnolds \& Boshoff, 2002: 698). Recognizing the achievements of employees, valuing them, giving support them in the issues they are inadequate, empowers them and motivates them to increase their success. However, the good and productive relationships they develop with colleagues are another main objective that must be fulfilled to motivate employees. The lack of such relationships and sharing at work can lead to loneliness at work (Stoica et al., 2014: 101). In this context, the hypothesis regarding the relationship between perceived psychological empowerment and loneliness in the workplace is presented based on the theoretical framework and empirical research.

$\mathbf{H}_{1}$ : Perceived psychological empowerment has negative and significant effect on loneliness at workplace.

According to the Organizational Support Theory, while meeting the socio-emotional needs of employees, and all kinds of support and empowerment activities aimed at increasing business skills and accordingly knowledge and experience levels positively affect employees' efforts to do their jobs and increase their internal status and performance, they also negatively affect behaviors such as burnout, job stress and loneliness (Shanock \& Eisenberger, 2006: 689; Eder \& Eisenberger, 2008: 56). The different behaviors that organizations exhibit for their employees constitute the perception that some of the employees are valuable to the organization as well as some of the others are expendable, and shapes the perceptions of employees related to internal or external status. (Buonocore et al., 2009). In this context, the empowerment activities provided to the employees by the organizations may be increase their perceptions about their internal status. Employees who have an increasing internal status perception may not feel alone and may exhibit positive organizational behaviours. Based on the theoretical framework and empirical research, the following hypotheses have been put forward to determine the effect between perceived psychological empowerment and perceived internal status and the effect between perceived internal status and loneliness in the workplace.

$\mathbf{H}_{\mathbf{2}}$ : Perceived psychological empowerment has positive and significant effect on perceived internal status.

$\mathbf{H}_{3}$ : Perceived internal status has negative and significant effect on loneliness at workplace.

In the literature, there are researches that perceived internal status used as a mediating variable. For example, perceived internal status has a full mediating role on the effect of leader-member exchange on organizational citizenship behavior (Wang, Chu \& Ni, 2010), perceived internal status has a partial mediating role on the effect of leader-member exchange on organizational cynicism (Kanbur \& Kanbur, 2015) and 
perceived internal status has a mediating role on the negative effect of poor supervision on proactive behaviors of subordinates (Ouyang et al., 2015). However, there is no study examining the mediating role of perceived internal perception in the effect of perceived psychological empowerment on loneliness at workplace. Taking consideration the researches that emphasizes the mediating role of perceived internal status, it has been thought that perceived internal status has a mediating role on the relationship between perceived psychological empowerment and loneliness at workplace. In this context, taking consideration the above mentioned theoretical perspectives in the first three hypothesis the hypotheses developed to test the mediating role of perceived internal status are described as in the following.

$\mathbf{H}_{4}$ : Perceived internal status has a mediating role on the relationship between perceived psychological empowerment and loneliness at workplace.

$\mathbf{H}_{4 \mathbf{a}}$ : Perceived internal status has a mediating role on the relationship between perceived psychological empowerment and emotional deprivation as a subdimension of loneliness at workplace.

$\mathbf{H}_{4 b}$ : Perceived internal status has a mediating role on the relationship between perceived psychological empowerment and lack of social companionship as a subdimension of loneliness at workplace.

\section{Methodology}

\subsection{Aim}

The aim of this research is to examine whether or not perceived internal status has a mediating role on the relationship between perceived psychological empowerment and loneliness at workplace and its subdimensions.

\subsection{Sample}

The population of the research is constituted by employees who are working in the governorship of one of our province. In this context, target population of the research approximately consists of 420 employees. In the process of conducting the research, necessary explanatory information about the research was given to the participants. Sample of the study composed of 219 employees and simple random sampling method was used in the study. Sample of the study is statistically acceptable to represent the target population and the data obtained from the sample are evaluated acceptable for the analyses of the study.

\subsection{Measures}

In the research, for gathering the data, questionnaire technique was used. The questionnaire form comprise of three scales in order to measure the related variables of the research. Each of the scales are in Five-point Likert-type ranging from "strongly agree" to "strongly disagree".

Being as one of these scales, "Psychological Empowerment Instrument-PEI", which was developed by Spreitzer (1995) and adapted to Turkish by Ertenü (2008) and also used by Çalışkan (2011) and proven to be reliable and valid, was used to determine psychological empowerment perceptions of the participants. The scale consists of four items each of which was taken from each dimension (meaning, competence, selfdetermination, impact) of the scale developed by Spreitzer (1995) as four dimension with 12 items. Due to meaning similarities of the items which measure the same dimension in the scale of Spreitzer, shortened form of the scale which was composed of four items in one dimension was also used in the researches (Ertenü, 2008; Çalışkan, 2011), and this shortened form also preferred in this study.

The scale of "Loneliness at Workplace Scale-LWS", which was developed by Wright, Burt and Strongman (2006), adopted to Turkish by Doğan, Çetin and Sungur (2009) and also used by Wright (2012), Mercan et al. (2012), Yılmaz and Aslan (2013), Ayazlar and Güzel (2014) and Peng et al. (2017) in their studies, and proven to be reliable and valid, was used to determine participants' loneliness at workplace. The scale consists of two subdimensions (emotional deprivation and social companionship) and 16 items. 
Perceived internal status of the employees was measured by "Perceived Internal Status Scale-PISC", which was developed by Stamper and Masterson (2002). The scale consists of six items in one dimension. It can be stated that the scale is accepted and used as a valid and reliable scale for measuring perceived internal status in national and international literature (Wang \& Kim, 2013; Akdoğan \& Köksal, 2014; Knapp et al., 2014; Ouyang et al., 2015).

\subsection{Reliability Analysis}

The internal consistency analysis of the scales of "Psychological Empowerment Instrument-PEI", "Loneliness at Workplace Scale-LWS" and "Perceived Internal Status Scale-PISC" was evaluated with the Cronbach Alpha Coefficient (Table 1). The Cronbach Alpha values of the scales are above $70 \%$, which is the acceptability limit for reliability.

Table 1. Reliability Analysis of the Scales

\begin{tabular}{lcc}
\hline \hline Scale & $\begin{array}{c}\text { Item } \\
\text { Number }\end{array}$ & $\begin{array}{c}\text { Cronbach } \\
\text { Alpha }(\boldsymbol{\alpha})\end{array}$ \\
\hline \hline Perceived Psychological Empowerment (PEI) & 4 & 0.789 \\
Loneliness at Workplace (LWS) & 16 & 0.848 \\
$\bullet$ Emotional Deprivation & 9 & 0.837 \\
$\bullet$ Lack of Social Companionship & 7 & 0.777 \\
Perceived Internal Status (PISC) & 6 & 0.805 \\
\hline
\end{tabular}

\subsection{Factor Analysis}

In the research, confirmatory factor analysis was utilized in order to measure the structural validity of the scales (Table 2).

Table 2. Confirmatory Factor Analysis of the Scales

\begin{tabular}{lcccccc}
\hline \hline Scale & CMIN/DF & RMSEA & GFI & AGFI & NFI & CFI \\
\hline \hline PEI & 1.708 & 0.057 & 0.993 & 0.963 & 0.986 & 0.994 \\
\hline LWS & 2.061 & 0.070 & 0.952 & 0.910 & 0.933 & 0.964 \\
\hdashline PISC & 1.312 & 0.038 & 0.989 & 0.960 & 0.981 & 0.995 \\
\hline PEI & $\begin{array}{l}\text { Psychological Empowerment Instrument } \\
\text { LWS }\end{array}$ & & & \\
PISC & Poneliness at Workplace & & & & \\
\hline
\end{tabular}

In Table 2, due to confirmatory factor analysis, fit values of the scales of perceived psychological empowerment, loneliness at workplace and perceived internal status were presented. When the fit values of the perceived psychological empowerment scale are examined, it can be seen that RMSEA value is 0.057; CMIN/DF is 1.708; GFI value is 0.993; AGFI value is 0.963 ; NFI value is 0.986 and CFI value is 0.994 . According to these findings, it can be stated that the one dimensional factor structure of the scale explained by Ertenü (2008) is confirmed in this study, and the scale has a good fit with its adapted Turkish version. When the fit values of the loneliness at workplace scale are examined, it can be seen that RMSEA value is 0.070 ; CMIN/DF 
value is $2.061, \mathrm{GFI}$ value is $0.952, \mathrm{AGFI}$ value is $0.910, \mathrm{NFI}$ value is 0.933 and $\mathrm{CFI}$ value is 0.964 . According to these findings, it can be stated that the two dimensional factor structure of the scale is confirmed in this study by having a good fit with its original. When the fit values of the perceived internal status scale are examined, it can be seen that RMSEA value is 0.038 ; CMIN/DF value is 1.312 , GFI value is 0.989 , AGFI value is $0.960, \mathrm{NFI}$ value is 0.981 and $\mathrm{CFI}$ value is 0.995 . According to these findings, it can be stated that the scale has a good fit with its original and its one dimensional factor structure is confirmed in this study. The research model which is revealed due to the findings of the confirmatory factor analysis is presented as in Figure 1.

Figure 1. Research Model

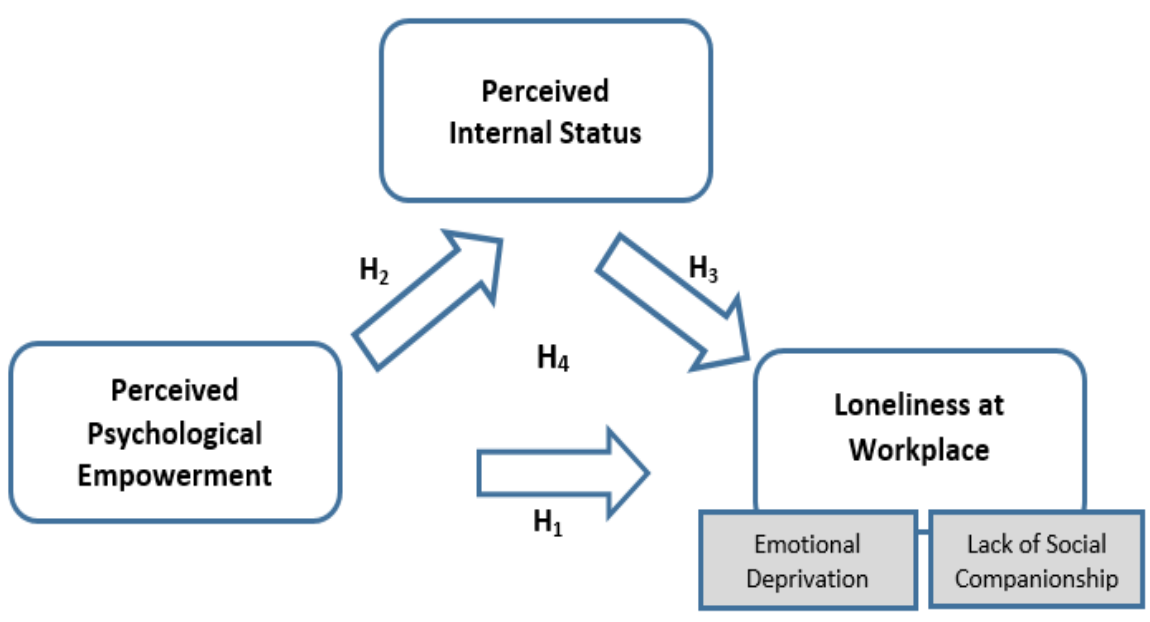

\section{Findings}

In this section, correlation analysis and regression analysis were utilized for determining the relationships between variables of the research and testing the hypotheses, and findings of these analyses were presented as in Table 3, Table 4 and Table 5.

\subsection{Correlation Analysis and Findings}

Correlation analysis was utilized for determining the relationships between variables of the research (Table 3).

Table 3. Correlation Analysis of Variables and Findings

\begin{tabular}{|c|c|c|c|c|c|c|c|c|}
\hline \multicolumn{2}{|c|}{ Variables } & Mean & SD & 1 & 2 & 3 & 4 & 5 \\
\hline 1 & $\begin{array}{l}\text { Perceived Psychological } \\
\text { Empowerment }\end{array}$ & 3.40 & 0.850 & 1 & & & & \\
\hline 2 & Loneliness at Workplace & 2.43 & 0.545 & $-0.203^{*}$ & 1 & & & \\
\hline 3 & Emotional Deprivation & 2.40 & 0.658 & -0.097 & $0.883^{*}$ & 1 & & \\
\hline 4 & Lack of Social Companionship & 2.48 & 0.637 & $-0.268 *$ & $0.783^{*}$ & $0.400 *$ & 1 & \\
\hline 5 & Perceived Internal Status & 3.42 & 0.753 & $0.254^{*}$ & $-0.416^{*}$ & $-0.433^{*}$ & $-0.239 *$ & 1 \\
\hline
\end{tabular}


According to the findings of correlation anaysis between variables of perceived psychological empowerment, loneliness at workplace with its subdimensions and perceived internal status presented in Table 3, it can be seen that there is a meaningful and positive relationship between perceived psychological empowerment and perceived internal status $(r=0.254 ; p<0.01)$. Also, there is a meaningful and negative relationship between perceived psychological empowerment and loneliness at workplace $(r=-0.203 ; p<0.01)$ and lack of social companionship $(r=-0.268 ; p<0.01)$ as subdimension of loneliness at workplace. But, there isn't observed any relationship between perceived psychological empowerment and emotional deprivation $(r=0.097 ; p>0.05)$ as the other subdimension of loneliness at workplace. Moreover, it can be seen that there is a meaningful and negative relationship between perceived internal status and loneliness at workplace and its subdimensions.

\subsection{Regression Analysis and Findings}

Regression analysis conducted for determining the relationships between variables of the research and its findings were presented in Table 4, and the hierarchical regression analysis conducted for determining the mediating role related to the variables of the research and its findings were presented in Tables 5 and 6 . Additionally, the presence of autocorrelation and the Durbin-Watson statistical value were also checked.

Table 4. Regression Analysis of Variables and Findings

\begin{tabular}{|c|c|c|c|c|c|c|c|}
\hline \multicolumn{8}{|c|}{ Dependent Variable: Loneliness at Workplace } \\
\hline Independent Variable & $\mathbf{R}^{2}$ & Adj. $R^{2}$ & $\mathbf{F}$ & $\beta$ & $\mathbf{t}$ & p & DW \\
\hline $\begin{array}{l}\text { Perceived Psychological } \\
\text { Empowerment }\end{array}$ & 4.1 & 3.7 & $9.315^{*}$ & -0.203 & -3.052 & $0.003^{*}$ & 1.766 \\
\hline Perceived Internal Status & 17.3 & 16.9 & $45.471^{*}$ & -0.416 & -6.743 & $0.000 *$ & 1.919 \\
\hline \multicolumn{8}{|c|}{ Dependent Variable: Perceived Internal Status } \\
\hline Independent Variable & $\mathbf{R}^{2}$ & Adj. $R^{2}$ & $\mathbf{F}$ & $\beta$ & $\mathbf{t}$ & p & DW \\
\hline $\begin{array}{l}\text { Perceived Psychological } \\
\text { Empowerment }\end{array}$ & 6.4 & 6.0 & $14.923 *$ & 0.254 & 3.863 & $0.000^{*}$ & 1.876 \\
\hline
\end{tabular}

According to the regression analysis findings in Table 4, it can be seen that $3.7 \%$ ( $A d j . R^{2}=, 037$ ) of the variable of loneliness at workplace is negatively and significantly $(\beta=-0.203 ; p<0.01)$ explained by the variable of perceived psychological empowerment. Thus, the first hypothesis $\left(\mathrm{H}_{1}\right)$ of the research is supported. Due to the findings, $6 \%$ (Adj. $R^{2}=0.06$ ) of the varibale of perceived internal status is positively and significantly $(\beta=0.254 ; p<0.01)$. explained by the variable of perceived psychological empowerment. Thus, the second hypothesis $\left(\mathrm{H}_{2}\right)$ of the research is supported. Findings demonstrate that $16.9 \%$ (Adj. $R^{2}=0.169$ ) of the variable of loneliness at workplace is negatively and significantly $(\beta=-0.416 ; p<0.01)$ explained by the variable of perceived internal status. Thus, the third hypothesis $\left(\mathrm{H}_{3}\right)$ of the research is supported. It can be also seen that there is no autocorrelation in all analyses ( $D W=1.5-2.5)$. 


\subsection{Hierarchical Regression Analysis and Findings}

Hierarchical regression analysis was used in the study to test the main hypothesis $\left(\mathrm{H}_{4}\right)$ and hypotheses $\left(\mathrm{H}_{4 a}, \mathrm{H}_{4 b}\right)$ related to the subdimensions of loneliness at workplace, and findings were presented in detail in Tables 5 and 6 . In other words, for testing whether or not perceived internal status has a mediating role on the relationship between perceived psychological empowerment and loneliness at workplace, hierarchical regression analysis was utilized. According to this analyze some assumptions need to be understood (Baron and Kenny, 1986):

1. Having a significant effect of independent variable (perceived psychological empowerment) on dependent variable (loneliness at workplace and its subdimensions),

2. Having a significant effect of independent variable (perceived psychological empowerment) on mediating variable (perceived internal status),

3. When the mediating variable participated to the model (perceived internal status), significance degree of the significant relationship between dependent variable (loneliness at workplace and its subdimensions) and independent variable (perceived psychological empowerment) required to be completely disappeared (full mediation) or decreased (partial mediation) in comparison to its first degree. Furthermore, whether the mediating effect (amount of the decrease in beta value) was significant was analyzed by the Sobel test.

Table 5. Hierarchical Regression Analysis of Variables for $\mathrm{H}_{4}$ and Findings

\begin{tabular}{|c|c|c|c|c|c|c|}
\hline $\begin{array}{l}\text { Model } 1 \\
\text { Independent } \\
\text { Variable }\end{array}$ & $\begin{array}{l}\text { Dependent } \\
\text { Variable }\end{array}$ & Adj. $R^{2}$ & $\mathbf{F}$ & $\beta$ & $\mathbf{t}$ & p \\
\hline $\begin{array}{l}\text { Perceived } \\
\text { Psychological } \\
\text { Empowerment }\end{array}$ & $\begin{array}{l}\text { Loneliness at } \\
\text { Workplace }\end{array}$ & 3.7 & $9.315^{*}$ & -0.203 & -3.052 & $0.003 *$ \\
\hline $\begin{array}{l}\text { Model } 2 \\
\text { Independent } \\
\text { Variable } \\
\end{array}$ & $\begin{array}{l}\text { Dependent } \\
\text { Variable } \\
\end{array}$ & Adj. $R^{2}$ & $\mathbf{F}$ & $\beta$ & $\mathbf{t}$ & $p$ \\
\hline $\begin{array}{l}\text { Perceived } \\
\text { Psychological } \\
\text { Empowerment }\end{array}$ & $\begin{array}{l}\text { Perceived Internal } \\
\text { Status }\end{array}$ & 6.0 & $14.923^{*}$ & 0.254 & 3.863 & $0.000 *$ \\
\hline $\begin{array}{l}\text { Model } 3 \\
\text { Independent } \\
\text { Variable } \\
\end{array}$ & $\begin{array}{l}\text { Dependent } \\
\text { Variable } \\
\end{array}$ & Adj. $R^{2}$ & $\mathbf{F}$ & $\beta$ & $\mathbf{t}$ & $p$ \\
\hline $\begin{array}{l}\text { Perceived } \\
\text { Psychological } \\
\text { Empowerment }\end{array}$ & Loneliness at & 17.6 & $24.249 *$ & -0.104 & -1.636 & 0.103 \\
\hline $\begin{array}{l}\text { Perceived Internal } \\
\text { Status }\end{array}$ & & & & -0.390 & -6.133 & $0.000 *$ \\
\hline
\end{tabular}

According to the findings in Table 5 , it can be seen that $17.6 \%$ (Adj. $R^{2}=0.176$ ) of the variable of loneliness at workplace is significantly $(\mathrm{F}=24.249)$ explained by the variables of perceived psychological empowerment and perceived internal status. However, the regression coefficient Beta's value of the variable of perceived psychological empowerment $(\beta=-0.203)$ decreased with the participation of the variable of perceived internal status $(\beta=-0.104)$ to the model, and completely disappeared $(p=0.103)$. Thus, main hypothesis of the research $\left(\mathrm{H}_{4}\right)$ is supported as "it has a full mediating role". 
Table 6. Hierarchical Regression Analysis of Variables for $\mathrm{H}_{4 a}, \mathrm{H}_{4 b}$ and Findings

\begin{tabular}{|c|c|c|c|c|c|c|c|}
\hline $\begin{array}{l}\text { Independent / } \\
\text { Mediator Variable }\end{array}$ & $\begin{array}{l}\text { Dependent } \\
\text { Variable }\end{array}$ & Adj. $R^{2}$ & $\mathbf{F}$ & $\beta$ & $\mathbf{t}$ & p & Sobel Test \\
\hline $\begin{array}{l}\text { Perceived } \\
\text { Psychological } \\
\text { Empowerment }\end{array}$ & $\begin{array}{l}\text { Perceived } \\
\text { Internal Status }\end{array}$ & 6.0 & $14.923^{*}$ & 0.254 & 3.863 & $0.000^{*}$ & - \\
\hline \multicolumn{8}{|l|}{ Model 1} \\
\hline $\begin{array}{l}\text { Perceived } \\
\text { Psychological } \\
\text { Empowerment }\end{array}$ & $\begin{array}{l}\text { Emotional } \\
\text { Deprivation }\end{array}$ & 0.5 & 2.051 & -0.097 & -1.432 & 0.154 & - \\
\hline \multicolumn{8}{|c|}{$\begin{array}{l}\text { * Mediating role is not analyzed for "emotional deprivation" because there isn't found any significant } \\
\text { relationship }(p>0,05) \text { between perceived psychological empowerment and emotional deprivation as } \\
\text { subdimension of lonesliness at workplace. }\end{array}$} \\
\hline \multicolumn{8}{|l|}{ Model 2} \\
\hline $\begin{array}{l}\text { Perceived } \\
\text { Psychological } \\
\text { Empowerment }\end{array}$ & & 6.8 & $16.828^{*}$ & -0.268 & -4.102 & $0.000 *$ & \\
\hline $\begin{array}{l}\text { Perceived } \\
\text { Psychological } \\
\text { Empowerment }\end{array}$ & $\begin{array}{l}\text { Lack of Social } \\
\text { Companionship }\end{array}$ & 9.5 & $12.445^{*}$ & -0.222 & 3.330 & $0.001^{*}$ & $\begin{array}{c}Z=2.7088 \\
p=0.00\end{array}$ \\
\hline $\begin{array}{l}\text { Perceived Internal } \\
\text { Status }\end{array}$ & & & & -0.183 & -2.748 & $0.006 *$ & \\
\hline
\end{tabular}

$*_{p}<0.01$

According to the findings in Table 6, it can be seen that there isn't found any significant relationship $(p>0,05)$ between the variable of perceived psychological empowerment and emotional deprivation as subdimension of the variable of lonesliness at workplace. Therefore, mediating role is not analyzed for "emotional deprivation" and $\mathrm{H}_{4 a}$ is not supported. When Model 2 in Table 6 is evaluated, it can be seen that 9.5\% (Adj. $\mathrm{R}^{2}=0.095$ ) of "lack of social companionship" as subdimension of the variable of loneliness at workplace is significantly $(F=12.445)$ explained by the variables of perceived psychological empowerment and perceived internal status. Additionally, the regression coefficient Beta's value of the variable of perceived psychological empowerment $(\beta=-0.268)$ decreased with the participation of the variable of perceived internal status ( $\beta=-0.222)$ to the model, but it is not completely disappeared ( $p=0.001)$. Thus, $H_{4 b}$ is supported as "it has a partial mediating role".

\section{Conclusion}

Human capital is the most indispensable resource for organizations. Organizations need human capital and its performance to keep pace with change and transformation in the global business world, to compete with their rivals, and ultimately to achieve their goals. However, it is not easy to raise performance of employees, increase their sense of belonging, and direct them to organizational goals. According to the social exchange theory, the norm of reciprocity and the organizational support theory, it is not advantageous for organizations to wait high performance from their employees without giving support to them, paying attention to their problems and completing their inadequacies. When organizations empower their employees as their most valuable source, they will increase their self-esteem and sense of belonging, provide them to socialize and participate in decision making and enable them to take more authority and responsibility.

According to the findings of the research; it can be seen that perceived psychological empowerment $\left(\mathrm{H}_{1}\right)$ and perceived internal status $\left(\mathrm{H}_{2}\right)$ have a negative and meaningful relationship with loneliness at workplace, and there is a positive and meaningful relationship found between perceived psychological 
empowerment and perceived internal status $\left(\mathrm{H}_{3}\right)$. Thus, the first, second and third hypotheses of the research are supported. These findings provide useful guidance about the importance of empowering employees. Due to the findings related to the hypothesis one, it can be understood that psychological empowerment should be enhanced to decrease loneliness at workplace. Similarly, findings of hypothesis two revealed that experiencing loneliness at workplace may be increased if employees have a decreasing internal status perception. It is possible to say that empowered employees and employees who have increasing levels perceived internal status may not feel loneliness at workplcae. Moreover, these employees tend to show positive organizational behaviours. To gain qualified employees and to met their needs, psychological empowerment should be provided to them. Findings related to hypothesis three demonstrates that employees who have an increasing psychological empowerment perception may exhibit increasing internal status perception.

Employees participate in organizations to realize a set of goals. First of all, meeting basic needs, socializing, being effective and productive, being a member of a group, securing their future and having a career are some of these goals. Organizations, in turn, need the labor to reach their goals as quickly as possible, efficiently and effectively, and to maintain sustainability. The fulfillment of the goals in both sides, within the framework of the win-win approach, requires some duties from organizations. Organizations can compete with their rivals and achieve their organizational goals when they provide necessary and sufficient support to their employees in their inadequate knowledge and skills, and empower them. Self-efficacy, performance, feelings of belonging and communication skills of employees may increase when they perceived that they have been empowered, and their feeling of loneliness may decrease. Yurcu and Kocakula (2015) emphasize in their research that empowering the social companionship level of employees increases their subjective well-being level and therefore their sense of belonging. Çetin and Alacalar (2016) point out in their research, inwhich they examine predictors of loneliness at workplace, that perceived social and organizational support has a negative effect on loneliness at workplace. To take support and empowered by organization about the inadequacies help employees to socialize. Thus, they don't feel loneliness at workplace.

It is emphasized in the findings of this research that perceived internal status has a full mediating role on the relationship between perceived psychological empowerment and loneliness at workplace. Thus, the fourth hypotheses of the research is supported. This indicates that perceived psychological empowerment directly decreases loneliness at workplace by the help of mediating role of perceived internal status. This finding can be seen as an indicator for the managers to become aware of psychological empowerment as a valuable management tool in creating haapy employees far from loneliness. Findings of the study signal the importance of a comprehensive acceptance of psychological empowerment and internal status perceptions of employees to enhance getting rid off loneliness at workplace. Organization's empowerment of their employees may increase their confidence and competence, increase their socialization and communication skills, but this may not be enough by oneself. Employees' perceiving and embracing themselves as a part of their organization can cause their feelings of loneliness to be reduced and/or completely disappeared. Another finding is that perceived internal status has a "partial mediating role" on the relationship between perceived psychological empowerment and lack of social companionship as subdimension of loneliness at workplace. But, there isn't observed any mediating role on the relationship between perceived psychological empowerment and emotional deprivation as subdimension of loneliness at workplace. In the light of these findings, it is possible to say that effects on the loneliness at workplace stem from the lack of social companionship as its subdimension. Ultimately, organizations can empower their employees to compete and survive, and increase their employees' sense of belonging to organization. Employees with high perceptions of psychological empowerment may feel less loneliness within the organization and their socialization levels may increase.

This study will not be free from limitations. Limitations of this study can be clarified as its sample, data gathering technique, statistical analyses and scales utilized for measuring the perceived internal status, perceived psychological empowerment and loneliness at workplace. Variables of the study were examined in the specific context of this study. Accordingly, future researches, can address the same problem or designed new research problems related to variables of the study. It is possible for future studies to add new 
variables to research model. This study is conducted with the participants from a public organization. Thus, future researches may examine the research problem in different samples. Future researches may also design a new methodology or use different statistical mechanisms to measure the variables and to reveal the relations between variables.

\section{References}

Altındiş, S., \& Özutku, H. (2011). Psychological empowerment and factors affecting psychological empowerment: A research in Turkey state hospitals. Journal of Social Sciences, XIII(1), 162-191.

Akar, H. (2015). The relationship between the workaholic tendencies and loneliness of instructors in workplace. The Journal of International Education Science, 2(5), 405-417.

Armağan, A. (2014). Loneliness and interpersonal communication ability relationship: A research on unıversity students. The Journal of International Social Research, 7(30), 27-43.

Avolio, B. J., Zhu. W., Koh, W., \& Puja, B . (2004). Transformational leadership and organizational commitment: Mediating role of psychological empowerment and moderating role of structural distance. Journal of Organizational Behavior, 25, 951-968.

Akdoğan, A. A., \& Köksal, O. (2014). The mediation role of trust in supervisor on the relationship between insider perception and organizational citizenship behavior. Journal of Social Sciences Institute, 18(1), 25-43.

Arnolds, C. A., \& Boshoff, C. (2002). Compensation, esteem valence and job performance: An empirical assessment of Alderfer's ERG Theory. International Journal of Human Resource Management, 13(4), 697-719.

Ayazlar, A. R., \& Ayazlar, G. (2016). The role of sense of belonging and life satisfaction on local people's attitude towards tourism effects. Journal of Social Sciences Institute, 20(4), 1451-1470.

Ayazlar, G., \& Güzel, B. (2014). The effect of loneliness in the workplace on organizational Commitment. Procedia - Social and Behavioral Sciences, 131, 319-325.

Aykan, E. (2014). Effects of perceived psychological contract breach on turnover intention: Intermediary role of loneliness perception of employees. Procedia-Social and Behavioral Sciences, 150, 413-419.

Bandura, A. (1995). Self-efficacy in changing societies (Ed. Albert Bandura). Cambridge: Cambridge University Pres.

Baron, M. R., \& Kenny, A. D. (1986). The moderator-mediator variable distinction in social pyschological research. Conceptual, strategic and statistical considerations. Journal of Personality and Social Psychology, 51(6), 11731182.

Başoğlu, B., Şekeroğlu, Ö. M. Altun, E., \& Dinçer, M. (2016). Examination of the relationship between teacher's loneliness in professional life and demographical characteristics. CBU Journal of Physical Education and Sport Sciences, 11(2), 66-76.

Buonocore, F., Metallo, C., \& Salvatore, D. (2009). Behavioural consequences of job insecurity and perceived insider status for contingent workers. System Congress, 1-29.

Cindiloğlu, M., Polatçı, S., Özçalık, F., \& Gültekin, Z. (2017). The effects of workplace loneliness on job and life satisfaction: The mediating role of leader-member exchange. Ege Academic Review, 17(2), 191-200.

Conger, J. A., \& Kanungo, N. R. (1988). The empowerment process: Integrating theory and practice. Academy of Management Review, 13(3), 471-482.

Çakal, M., \& Özdemir Y. (2016). Perceived insider status of emergency medical services workers. Suleyman Demirel University The Journal of Visionary, 7(14), 105-118.

Çalışkan, S. C. (2011). Impact of workplace friendships and organizational communication on employees perceptions of psychological empowerment. Journal of Social Sciences Institute, 20(3), 77-92.

Çetin, A., \& Alacalar, Ç. A. (2016). The role of personality traits, perceived organizational and social support in predicting Ioneliness in the workplace. Int. Journal of Management Economics and Business, 12(27), 193-216.

Demirbaş, B., \& Haşit, G. (2016). Loneliness at workplace and its effect on the intention to leave: An application on the academicians. Anadolu University Journal of Scial Sciences, 16(1), 137-158.

Doğan, T., Çetin, B., \& Sungur, M. Z. (2009). Reliability and validity of the turkish version of loneliness at work scale. Anatolian Journal of Psychiatry, 10, 271-7.

Eder, P., \& Eisenberger, R. (2008). Perceived organizational support: Reducing the negative influence of coworker withdrawal behavior. Journal of Management, 34(1), 55-68.

Erdil, O., \& Ertosun, Ö. (2011). The relationship between social climate and loneliness in the workplace and effects on employee well-being. The 7th International Strategic Management Conference, Paris.

Eroğluer, K., \& Yılmaz, Ö. (2015). The effect of ethical leadership behavior on perceived organizational climate: Mediating role of work loneliness. Journal of Business Research-Türk, 7(1), 280-308. 
Mediating Role of Perceived Internal Status on the Relationship Between Perceived Psychological Empowerment and Loneliness at Workplace

Ertenü, B. (2008). The role of psychological empowerment between managerıal practices and organizational citizenship behavior. PhD Thesis, Marmara University, İstanbul.

Evans, J. R., \& Lindsay, W. M. (1993). The management and control of quality (2nd Ed.). West Publishing Company.

Ghadi, Y. M. (2017). The impact of workplace spirituality on voluntary turnover intentions through loneliness in work. Journal of Economic and Administrative Sciences, 33(1), 81-110.

Hales, C., \& Klidas, A. (1998). Empowerment in five-star hotels: Choice, voice or rhetoric? Contemporary Hopitality Management, 10(3), 88-95.

Hall, M. (2008). The effect of comprehensive performance measurement systems on role clarity, psychological empowerment and managerial performance. Accounting, Organizations and Society, 33, 141-163.

Hidalgo, M. C., \& Hernandez, B. (2001). Place attachment: Conceptual and empirical questions. Journal of Environmental Psychology, 21, 273-281.

Horng, J. S., Tsai, C. Y., Hu, D. C., \& Liu, C. H. (2016). The role of perceived insider status in employee creativity: developing and testing a mediation and three-way interaction model. Asia Pacific Journal of Tourism Research, 21(1), 53-75.

Hu, S. L. Y., \& Leung, L. (2003). Effects of expectancy-value, attitudes, and use of the internet on psychological empowerment experienced by Chinese women at the workplace. Telematics and Informatics, 20(4), 365-382.

Hui, C., Lee, C., \& Wang, H. (2014). Organizational inducements and employee citizenship behavior: The mediating role ofperceived insider status and the moderating role of collectivism. Human Resource Management, 54(3), 439456.

Jha, S. (2014). Transformational leadership and psychological empowerment determinants of organizational citizenship behavior. South Asian Journal of Global Business Research, 3(1), 18-35.

Kanbur, A., \& Kanbur, E. (2015). The effect of leader - member exchange on organizational cynicism: The mediating role of perceived internal status. Zeitschrift für die Welt der Türken, 7(2), 193-216

Kanbur, E. (2018). Investigation of relationships between psychological empowerment, job performance and intention to leave in aviation sector. Int. Journal of Management Economics and Business, 14(1), 147-162.

Kanbur, E., Canbek, M., \& Özyer, K. (2016). The effect on perceptions of self-sufficiency of employees of role ambiguity and role conflict in organizations. Journal of Organizational Behavior Research, 1(1), 16-34.

Karakaş, A., \& Serçek, S. (2014). The impacts of psychological empowerment perception on organizational loyalty: A research on hotel employees. Journal of Travel and Hospitality Management, 11(2), 90-107.

Karakaya, A., Büyükyılmaz, Ö., \& Ay, A. F. (2015). The effect of workplace loneliness on workaholism: A study in Kardemir Inc.. Journal of Management and Economics Research, 13(3), 79-100.

Kesen, M. (2015). Does psychological empowerment decrease social loafing behaviors of employees? Journal of Yasar University, 10(38), 6478-6554.

Keser, A., \& Karaduman, M. (2014). The correlation between loneliness at work-life and organizational citizenship and a research on teachers. HAK-iş International Journal of Labor and Society, 3(7), 178-197.

Kim, T. Y., Hon, A. H., \& Crant, J. M. (2009). Proactive personality, employee creativity, and newcomer outcomes: A longitudinal study. Journal of Business and Psychology, 24(1), 93-103.

Knapp, J. R., Smith, B. R., \& Sprinkle, T. A. (2014). Clarifying the relational ties of organizational belonging: Understanding the roles of perceived insider status, psychological ownership, and organizational identification. Journal of Leadership \& Organizational Studies, 21(3), 273-285.

Kunst, M., Bogaerts, S., \& Winkel, F. W. (2010). Domestic violence and mental health in a Dutch community sample: The adverse role of loneliness. Journal of Community \& Applied Social Psychology, 20, 419-425.

Lam, L. W., \& Lau, D. C. (2012). Feeling lonely at work: Investigating the consequences of unsatisfactory workplace relationships. The International Journal of Human Resource Management, 23(20), 4265-4282.

Laschinger, H. K. S., Finegan, J. E., Shamian, J., \& Wilk, P. (2004). A longitudinal analysis of the Impact of workplace empowerment on work satisfaction. Journal of Organizational Behavior, 25(4), 527-545.

Masterson, S. S., \& Stamper, C. L. (2003). Perceived organizational membership: An aggregate framework representing the employee-organization relationship. Journal of Organizational Behavior, 24(5), 473-490.

Mercan, N. Oyur, E. Alamur, B. Gül, S., \& Bengül, S. (2012). A resource on the relationship between loneliness at work and social phobia. Journal of Organization and Management Sciences, 4(1), 213-226.

Oğuz, E., \& Kalkan, M. (2014). Relationship between loneliness and perceived social support of teachers in the workplace. Elementary Education Online, 13(3), 787-795.

Ouyang K., Lam W., \& Wang, W. (2015). Roles of gender and identification on abusive supervision and proactive behavior. Asia Pacific Journal of Management, 32, 671-691.

Peng, J., Chen, Y., Xia, Y., \& Ran, Y. (2017). Workplace loneliness, leader-member exchange and creativity: The crosslevel moderating role of leader compassion. Personality and Individual Differences, 104, 510-515.

Rokach, A. (2014). Leadership and loneliness. International Journal of Leadership and Change, 2(1), 48-58. 
Robbins, S. P., \& Decenzo, D. A. (2001). Concepts, controversies and applications: Organizational behaviour. New Jersey: Prentice Hall.

Rook, K. S. (1984). Promoting social bonding: Strategies for helping the lonely and socially isolated. American Psychologist, 39, 1389-1407.

Russell, D., Cutrona, C. E., Rose, J., \& Yurko, K., (1984). Social and emotional loneliness: An examination of Weiss's typology of loneliness. Journal of Personality and Social Psychology, 46(6), 1313-1321.

Shanock, L., \& Eisenberger, R. (2006). When supervisors feel supported: relationships with subordinates' perceived supervisor support, perceived organizational support and performance. Journal of Applied Psychology, 91, 68995.

Singh, M., Gupta, A., \& Handa, P. (2015). Domain satisfaction predictors of psychological empowerment and determinants. Journal of Strategic Human Resource Management, 4(2), 56-64.

Spreitzer, G. M. (1995). Psychological empowerment in the workplace: Dimensions, measurement, and validation. The Academy of Management Journal, 38(5), 1442-1465.

Spreitzer, G. M. (1996). Soeiai struetural characteristies of psychologieal empowerment. Academy of Management Journal, 39(2), 483504.

Spreitzer, G. M., Kizilos, M. A., \& Nason, S. W. (1997). A dimensional analysis of the relationship between psychological empowerment and effectiveness, satisfaction, and strain. Journal of Management, 23(5), 679-704.

Spreitzer, M. G. (2007). Taking stok: A review of more than twenty years of research on empowerment at work. In J. Barling \& CP. Cooper (Ed.), Sage handbook of organizational behaviour. Thousand Oaks, CA: Sage.

Sürgevil, O., Tolay, E., \& Topoyan, M. (2013). The validty and reliability analysis of structural empowerment and psychological empowerment scales. Journal of Yasar University, 8 (31), 5371-5391.

Stamper, C. L., \& Masterson, S. S. (2002). Insider or outsider? How employee perceptions of insider status affect their work behavior. Journal of Organizational Behavior, 23(8), 875-894.

Stamper, C. L., Masterson, S. S., \& Knapp, J. (2007). A typology of organizational membership: Understanding different membership relationships through the lens of social exchange. Management and Organization Review, 5(3), 303328.

Stoica, M., Brate, T. A., Bucuta, M., Dura, H., \& Morar, S. (2014). The association of loneliness at the workplace with organisational variables. European Journal of Science and Theology, 10(5), 101-112.

Taştan, Ş. (2012). The examination of the moderating role of organizational identification as being a positive psychology concept on the relationship between psychological empowerment and voluntary performance behavior: A research in food sector. Journal of Organization and Management Sciences, 4(1), 227-238.

Toplu, D., \& Akça, M. (2013). The effect of learning organizations on psychological empowerment: A research in public sector. Istanbul Commerce University Journal of Social Sciences, 12(23), 221-235.

Wang, L., Chu, X., \& Ni, J. (2010). Leader-member exchange and organizational citizenship behavior: A new perspective from perceived insider status and Chinese traditionality. Frontiers of Business Research in China, 4(1), 148-169.

Wang, J., \& Kim, T. Y. (2013). Proactive socialization behavior in China: The mediating role of perceived insider status and the moderating role of supervisors' traditionality. Journal of Organizational Behavior, 34 (3), 389-406.

Weiss, R. S. (1973). Loneliness: The experience of emotional and social isolation. Cambridge, MA: The MIT Press.

Whitakera, G. B., \& Westerman, W. J. (2014). Linking spirituality and values to personal initiative through psychological empowerment. Journal of Management, Spirituality \& Religion, 11(3), 269-291.

Wright, S. L. (2005). Loneliness in the workplace. PhD Thesis, University of Canterbury.

Wright, S. L., Burt, C. D. B., \& Strongman, K. T. (2006). Loneliness in the workplace: Construct definition and scale development. New Zealand Journal of Psychology, 35(2), 59-68.

Wright, S. L. (2012). Is it lonely at the top? An empirical study of managers' and nonmanagers' loneliness in organizations. The Journal of Psychology, 146(1-2), 47-60.

Yıldırım, H. (2011). Personel güçlendirme-empowerment: Çağdaş bir yönetim yaklaşımı. In í. Bakan (Ed.), Çağdaş yönetim yaklaşımları: Illkeler, kavramlar ve yaklaşımlar (pp.93-111). İstanbul: Beta Yayınları.

Yılmaz, A., \& Aslan, H. (2013). Examination of relationship between teachers' loneliness at workplace and their life satisfaction. Pegem Journal of Education \& Instruction, 3(3), 59-69.

Yurcu, G., \& Kocakula, Ö. (2015). The effect of worker loneliness in workplace on subjective well-being in hospitality. Adnan Menderes University Journal of Social Sciences Institute, 2(1), 30-41.

Yürür, Ş., \& Demir, K. (2011). An analysis of the relationships between organizational justice and psychological empowerment. Suleyman Demirel University The Journal of Faculty of Economics and Administrative Science, 16(3), 311-335.

Zimmerman, A. M. (1995). Psychological empowerment: Issues and illustrations. American Journal of Community Psychology, 23(5), 581-599. 
This Page Intentionally Left Blank 